\title{
Study of George Eliot's Selected Works in the Light of Germaine Greer's Ideas
}

\author{
Hasti Soltani \\ Ershad_Damavand University, Tehran, Iran
}

\begin{abstract}
Feminism is a movement that aims to establish equal rights and opportunities for women. George Eliot, the British female writer, is among the practitioners who try to depict these elements in her novels. Her two major novels, The Mill on the Floss and Middlemarch: A Study of Provincial Life are great supports for her Feminist ideologies. Bearing a good resemblance to Eliot's own life, the women protagonists of these novels, Maggie and Dorothea, are considered as proper models of critical study by great feminist critics such as Germaine Greer, a modern feminist critic whose valuable contribution to the world of literature as well as to the real world is illustrated in her book The Female Eunuch. Greer focuses on liberation, nuclear family, and revolution as the major elements which are the basis of these protagonist's lives and characters from childhood to womanhood.
\end{abstract}

Index Terms-Dorothea, Eunuch, feminism, gender studies, George Eliot, Maggie, Middlemarch, The Mill on the Floss

\section{INTRODUCTION}

Germaine Greer is the contemporary Australian feminist known specifically by her book, The Female Eunuch, which gives the readers a powerful insight into the female condition and brought its author both acclaim and criticism. The researcher has chosen to write on Greer due to three major reasons: first, the rare information about her; second reason is her novelty; and the last but not the least is her radical statements due to women liberation and radical feminism. In addition, George Eliot is one of the leading female English Victorian novelists whose powerful personality and restless intelligence shaped her life; and like Greer, she has lived by extremes with anarchist ideas in a suffocating male dominant society with no rights for women and no place for the "second sex."

Regarding Greer's theories, the researcher tries to analyze Eliot's female protagonists, Maggie and Dorothea of The Mill on the Floss and Middlemarch, respectively, and to explore the traces of women's restriction and suppression by men in different types of communities. Eliot is the pseudonym of Mary Ann Evans (1819-1880), one of the leading English Victorian novelist, and translator who lived in a suffocating male dominant society. She published articles, edited a periodical, refused to marry until she was middle-aged, lived an independent existence as a spinster, and finally lived openly with a married man whom she could not marry. "By adopting this name, she paid tribute to the man who nurtured her literary efforts, George Henry Lewes (Gilbert \& Gubar,1996, p. 799). Like Greer, she makes the ground breaking liberator female with anarchist ideas. She is identifying with her heroine seeks honor in her ideals of love and charity, somehow she symbolizes new law. Maggie's need of love is described as a "hunger of the heart (Moldstad, p.527).

Restrictions caused women to be considered as the "second sex" in the patriarchal society of Victorian era. Being different from the other girls of her age, Maggie, the rebellious girl, is criticized because of not following the stereotypes. Dorothea, like Maggie, is a different girl with big ambitions and in search of finding a way to get rid of social constrains. Both are tired of the injustice imposed on them, and both make a great opportunity to touch these feminist perspectives in real life. Accordingly, the present study aims to answer the following questions and elaborate these points.

- Are the social conditions responsible for Maggie and Dorothea's restrictions; and how could they change the conventions?

- How could the concepts of liberation, revolution and family be traced through Greer's theories?

In order to answer these questions, the research first deals with the preliminary image of feminist movement specifically Greer's critical theories on Liberation, Nuclear Family, and Revolution, and then scrutinizes the basic grounds of Greer's ideology through Eliot's The Mill on the Floss and Middlemarch, the two Victorian literary works in which the imposed limitations on women by the society escalated difficulties for women who were neither considered as an crucial nor enjoying the legal rights such as the right of voting, suing, or owning property.

\section{General BACKGROUND}

During the history we have always been observed the efforts of women for equality and for changing the roles in the male-privileged society which are totally beneficial for men. In order to refine these roles, we should first find the social forces strengthening patriarchy. The most important elements for gaining women's value are female individuals or the 
groups who are able to gain this power and influence all over the world. Characterization is a way through which women's right is possible to be promoted; and criticizing women's conditions in society contributes to the struggle for women's right and liberation in the world outside fiction. "Women cannot be simply depicted and classified as angels or demons, saints or whores, brainless housewives or eccentric spinsters. Such characterizations must be continually identified and then challenged" (Bressler, 1994. P.183).

All the insults led to the formation of the feminist movement or the Women's Liberation Movement which had started by Mary Wollstonecraft's A Vindication of the Rights of Woman in 1869, demanding social and moral equality of sexes. About seventy years later, women succeeded to gain the right to vote. "This fight for equality was later termed the first-wave of feminism." The "second-wave" began in the early 1960's and ran through the late 1980's. In this wave, women strived to reach a further sense of equality with men and to allow women to have a greater control over their body and the protection from physical abuse" (Sink, 2011, p. 1).

Studying the language of The Mill on the Floss that lies on human dilemma and conflicts between the convections of society and individual needs, Mary Jacobus focuses on the function of language as a starting point for a feminist analysis ironizing the maxims it creates, and demonstrates how society condemns women's privileged access to unreliable language and clichés which have replaced the (Grabes, 1989, p.157-158). Hegan also refers to Maggie's struggle for power, self-assertion and self-denial as well as her dilemma in finding a mate as a matter of heterosexual option and the conflict between conventions of the society and individual judgment (Fraiman, 1993, p.136).

Germaine Greer, the Australian feminist writer born in 1939, dedicates her life to feminist issues. She deals with female oppression and the imposed pressures on women by society and is greatly influenced by Simon de Beauvoir, who is the prominent feminist and the master of gender studies and introduces the concept of The Second Sex. To her, "one is not born, but rather becomes a woman" (Butler, 1990,p. 35) by society that forces her to follow the feminine stereotypes.

Additionally, a growing interest in cultural studies and gender studies in late 1950s and early 1960s, led to focusing on gender as the outcome of social and cultural traditions, not to the pure state of being born as a male or a female. Cultural studies, gender studies, and feminism all help women make themselves freed from social and cultural limitations.

Since the novels under study and Greer's feminism, which criticizes the patriarchal domination over women at different levels and in different situations, have less taken into consideration so far, the researcher tries to highlight women's roles and positions in Victorian male dominated society where the role of women was only housekeeping and rearing children with no legal right of voting or owning property, no education and outward activities.

\section{THE ARGUMENT}

For a long time, women have been degraded naturally weak as a sexual object, "a lower state of civilization...inferior to men" (Darwin, 1896, p. 563-564). Therefore, they are in need for tutelage from powerful and intelligent males (Montessori, 2004, p. 5-6). This prudish belief is rooted back in the ancient times, "from the Hebrew Bible and Greek philosophic writings to present, the female tends to be seen as the idealized projections of men's desires, the 'Angel in the House' and the demonic projections of men's sexual resentment and terrors, and the sources of all evil." They were identified by "negative reference to a kind of non-man, by her lack of ... male powers" (Abrams, 1999, p.89).

The old, unfair idea of male superiority and female inferiority in physical and intellectual aspects leads women to start a movement for the natural rights they have been deprived of and to stand against the clichés (Greer, 2006, p. 267). "In societies, women must follow the defined cliché and "embrace the stereotypical version of adult femininity produced by men" in their own benefits. Greer writes that: "women... develop a sense of shame about their own bodies. They also lose any natural and political autonomy. Thus, they are "left powerless" and "isolated" (Greer, 2006, p.65-68). Thus, to reopen the possibilities for development," women must learn about their "own bodies and the feminine normality" (p.31). In order to get rid of these boundaries, to "articulate their social constructs of what it means to be a woman, and to reject being labeled as the other," women need to know themselves, see themselves as "autonomous beings...[and] reject the social construct that men are subject" (Bressler,1994,p.173). The women, being studied here, led themselves to a dramatic representation that requires a minimum of expository interpretation (Parlett 103).

Greer rails against the social status and psychological oppression of women in her contemporary society. She sees man as merciless to woman from the standpoint of personal behavior...exempts her from anything in the way of contractual morality. An anonymous writer in her or his article, Feminist Perspectives on Family and Reproduction (2004) explains in the best way "Western consumer society and its interrelated attitudes toward reproduction, contraception, and family," and encourages women to reclaim their own legal rights, and to ban the old traditions through their own means (body acceptance) (www.pla...).

The condition of women who were considered as the second sex in the Victorian patriarchal society was so regretful because of restrictions and obstacles. There are two types of women: 1. Maggie and Dorothea in minority (despite of all limitations of that time Maggie is successful to fulfill her dreams and accepts the consequent outcomes while Dorothea does not achieve her goals); 2. Other female characters who give up deliberately. Greer focuses on the realms of women's liberation, nuclear family, and revolution. These basic elements portray Maggie and Dorothea's lives and characters from childhood to womanhood. She argues that this liberation does not mean equality with men, but gaining 
freedom over our own fate. Nuclear family is the origin for women's repressions and evolution demanded by women is achieved by revolution (Greer, 2006, p. 267-268).

\section{LIBERATION}

Male dominated society suppresses women, and makes them be submissive and sacrificing. The result is that they develop a sense of shame about their own bodies, lose any natural and political autonomy, and are "left powerless, isolated, and suffering a diminished sexuality and general unhappiness." The only solution for gaining liberation is not to compromise and to accept the rules of androcentric society and "the stereotypical version of adult femininity produced by men" but to accept women selves and to revolt against the strict rules imposed upon them on behalf of conventional society. Nuclear family is an obstacle for reaching liberation which is fulfilled totally by encountering the negative outcomes of the nuclear family. To Greer, women should know themselves, and the only key to their liberation is sexual liberation gained by body acceptance (p.65-68).

Greer's general idea about women's liberation is accepting the gender differences in a positive way to obtain freedom that helps them be a person, with dignity, nobility, passion, and pride all together shape their personhood. However, "women in the world are still afraid, mute and loaded by religion with all kinds of fetters (Greer, 2003, p.9-12). They need to challenge patriarchy through a "process of conscious-raising, women's liberation and a revolutionary change," by defining their own value system and gaining sovereignty over their own fates (Ray,2011, p.12). She believes that it is impossible to argue a case for women's liberation without any knowledge about their "bodies and the feminine normality in order to reopen the possibilities for development." She says, "we know what we are, but do not know what we may be" (Greer, 2006, p.31).

Greer deals with the relation of body and soul and the formation of stereotype born where the body meets the soul; the process through which woman becomes more body than soul, more soul than mind (Greer,2006, p.63). But the rise of civilization led to formation of customs and clichés, passivity and suppression of women, and also made them involved in trifles. It was beneficial for men, who continued it until women's energy deflected. Repression is the outcome of denial of female sexuality and the result of deflected energy. To Greer, it is the time to reject masculinefeminine polarity to which woman has been subjected from the cradle (Greer, 2006, p.78- 79). The differences between boys and girls, including physical and mental differences, many of which are evident from birth and may even be hardwired, affects their attitudes (Sethi, 2011, p.1).

\section{NUCLEAR FAMILY}

Greer rebels against women's social and psychological oppression rooted in family in modern society. She sees the nuclear family "as the origin for women's repressions which eventually transfer to society," a poor environment where girls are feminized from childhood by being taught rules subjugating and making them inferior to men. These oppressed girls grow up with a sense of shame about their own bodies, and deflect their energy, and it leads to destructive behavior. They learn the customs of the society by which they are surrounded, and acquire and accept values and behaviors appropriate to their community (Greer, 2006, p.268). The passage of time had a great influence on the life pattern in androcentric society. In the past, father was the absolute governor no way of disobeying his rules and challenging his orders. A typical family consisted of parents and the offsprings, as the sons grew up they learnt their male role from father and joined the father's career; and when it was the marriage time, family chose him the right girl, who was traditionally reared under the father's authority, and now her cell changed with a new warder.

Finding a way to escape, they embrace the stereotypes of femininity, and are left powerless, isolated, and unhappy, and this "devitalizes them, rendering them eunuchs." The only solution is changing the traditional, stereotypical childrearing system, the "consumerist, nuclear family" which "represses women sexually" (Miller, 2011, p.1).

There are different stages in human beings' lives but childhood and adulthood are the two main ones, being divided by puberty - a change in the variety of produced hormones cause the transformation of brain, bones, skin, and sex organs as well as the psychological status. Therefore, "a girl whose spirits have been dampened by inactivity, or innocence tainted by false shame, will always be a romp" (twi...). According to Joyce Nicholson in What Society Does to Girls: puberty is hell for boys and girls; for boys it is a matter of adjusting to physical changes (p.27), but the girls have to arrive at the feminine posture of passivity and sexlessness, and to abandon their autonomy. A girl has been subjected to more control and supervision than her brother, living in an andocentric society of no room for being worried, so she is required to adopt the proper feminine passivity and continue her repression by herself (Greer, 2006, p.96). Puberty is the matter of how to act young manly or young womanly. Thus, an anxious girl in suffocating malecentered society gradually learns that she does not have any identity alone, her identity has meaning only through the man next to her.

A few of them may refuse the imposed duties and rebel against them, ask for their own legal rights, try to be independent, not to be influenced or controlled by others although they face with and hindered by many obstacles (Greer, 2006, p.268).

Such a polarity causes many troubles for women who earn less than men for equal work, and are more responsible and industrious by nature. Nowadays many females have essential jobs in need of skills with low payments. However, 
we still witness discrimination and sexism in human societies. Greer tries to reveal that any sexual difference in intellectual capacity between males and females is irrelevant. There is no difference between the two sexes just because of the male-dominated society trivial stuffs given to women (Greer, p.118-119). However, there are major differences between men and women. But we must bear in our mind neither to judge the differences, to try to change them, nor to make them go away. We need to accept that individual differences exist. To get along, we must accept and respect the differences while communicating, expressing care and concern, and solving conflicts. These are some rules of communicating with opposite sex that if being observed, we can have an efficient relationship otherwise we lose it (p.158). Refusal of rules causes problems for us and our communities.

In healthy, love the false assumption of female passivity and male activity do not exist. Furthermore Greer in The Female Eunuch announces :"Our lifestyle contains more Thanatos than Eros, for egotism, exploitation, deception, obsession, and addictions have more place in us than eroticism, joy, generosity, and spontaneity (p.167). Talking about love and falling-in-love were radical ideas, problematic and even dangerous, a taboo in the sixteenth century but the transformation little by little appeared. The main reason for such change was Renaissance, when man was the squire of the home and woman submissive and his possession, as well as the increase of man's knowledge.

\section{REVOLUTION}

Thinking or talking about revolution brings to our mind "the violence of the revolution" (Sutherland, 2015, p.2). But Greer's theories, although controversial, do not cause violence. She argues that "change had to come about via Revolution not evolution" (Greer, p.367-371); "Revolution is in accord, and often associated with, a creative and revolutionary movement of the period. Women should seek a revolution in their circumstances by training themselves as a fighting force" (p.353). What Greer offers for creating a change women's current conditions is "Modification of an existing constitution" (www.en.wiki...) with no violence. She says that this revolution must be fulfilled without war. Later she adds, "Women who adopt the attitude of war in their search of liberation condemn themselves to acting out the last perversion of dehumanized manhood ( Magas, 1971, 1) and it would be genuine revolution if women would stop loving the victors in violent encounters" ( $\mathrm{p} .354-355)$. These suggested solutions are easy to practice but the researcher believes through these ways we cannot achieve our goals.

Due to the false idea that man stands for mind, wisdom, will and power, just the male essence was enough for being a ruler, a master. In Engeles's view, it is a kind of "slavery," within the family in which husband "is the bourgeois" and wife the proletariat" (in The Origin of the Family 1). So, where is the female position? What are her duties? Her duties are just definable through men around them; their fathers, brothers, husbands, and sons. In the childhood, they have to follow fathers' rules (depending on their situation their brothers'), after marriage obey their husbands, and by having children be at their service, ignoring all their needs and forgetting their identities. They accept the culturally determined identification of gender as they become ashamed of their bodies and lose their ability to have autonomy. They are left powerless and separated, unable to experience authentic joy.

Gradually, women got tired of the injustice imposed upon them, realizing that they are human beings not slaves. They began to rebel against their roles in society (Eugene Cho, 2011, p.1), to fight against female oppression by male in the hope of changing their condition to get rid of male sovereignty. They insisted on their equal standing and equal pay. This "may be understood as revolt against the limitations of the female role of passivity, hypocrisy, and indirect action, a rejection of the brutality and mechanicalness of male passion" (Greer, 2006, p.330). They opposed to segregation, to any social role determined by sex, any rule determining the wife as the quiet housewife, and the husband as the authoritarian head of the family. They asked for legitimate rights in marriage and control of property, believing that women should take as active role in social and economic stages as men do.

All these actions took place for liberation: the right to vote for women; a rejection of the imposed inequalities and injustice on women and a cry for equality. However, to the 'radical feminists,' labeled as according to Lvan Isaiah Spencer in his thesis Rethinking Responding to Raymond: Re_replying to reproaches to Transsexalism':cultural feminists,' the primary goal of feminism is to make women aware of "the imposition of so-called 'male values,"' and to create "an alternative culture based on 'female values."' They asserted women suppression based on gender identity, social class, attractiveness, sexual orientation, and ability, and believed that eliminating patriarchy, and other systems which perpetuate the domination of one group over another, will liberate everyone from an unjust society (Bailey, 2008, p.1350).

It is painful that women are considered as men's possession and judged by their beauty not by their power and mind. "The unique consciousness or sensibility of women... point to the idea that female biology is the basis of women's power. Biology is hence the source and not the enemy of the feminist revolution" (Echols, 1989, p.250).

Focusing on body acceptance as the only key to women's liberation, Greer expresses her idea about freedom and the way of gaining it. As Kimberly Trusdale expresses in her article Small Things : "If freedom is an out_of_body experience ..." "The female eunuch wants to be at ease in her body, unembarrassed about her body" (www.kim...), proud and protective of her body...to be free from forever criticizing it, seeking "a revolution in their circumstances by training themselves as a fighting force" without war (Greer, 1999, p.353). The struggle for liberation "becomes a struggle to defend the female body" which is our strength not enemy (p.418). Adopting the attitude of war in search of 
liberation, women condemn themselves to act out the perversion of dehumanized manhood they should abandon violence as an inhuman act and mock for men's overestimation of themselves.

\section{ELIOT'S THE MILL ON THE FLOSS IN THE LIGHT OF GERMAINE GREER's IDEAS}

The autobiographical, realistic novel of The Mill on the Floss is the story of Maggie Tulliver and her relationship, her defeat to confront fanatic society and its traditional rules. Though her brother, Tom, is less studious than Maggie, Mr. Tulliver decides to pay for Tom's additional education. Mr. Tulliver is rendered bankrupt. Tom returns home to support the family. The Mill is up for auction, and Lawyer Wakem, their father's enemy, buys the Mill. Maggie, an impetuous girl, cannot get along with restrictions, and escapes to gypsies to become a queen of gypsies. She seeks a higher order than social conventions, and so is rejected by her family and society. She struggles between impulse and duty to define herself as an individual. She befriends the crippled Philip, Lawyer Wakem's son. One bright spot is the return of Bob Jakin, Tom's childhood friend, into their lives. Bob buys books for Maggie. It causes her spiritual awakening. Philip and Maggie meet secretly, and then both confess their loves. Tom discovers, cruelly upbraids Philip, and makes Maggie not to see Philip again. Tom can pay off Mr. Tulliver's debts. But in an argument, Mr. Tulliver falls ill and finally dies. Several years later, Maggie, who has been teaching in another village, returns to St. Ogg's. She meets Stephen Guest, Lucy's, her cousin, Suiter. Maggie and Philip renew their close friendship, and accept to marry if Philip's father approved. Lawyer Wakem agrees. But Stephen and Maggie become attracted to each other. Stephen begs her to marry him. She decides to part with him and return to St. Ogg's where she is treated as a fallen woman and a social outcast. Tom renounces her, and Maggie goes to lodge with Bob Jakin and his wife. Maggie is befriended only by the Jakins and the clergyman. She bears the burden of the pain she has caused others and must endure the result. In flood, Maggie rescues Tom, who is trapped in the house, and they row down river to save Lucy but the boat is capsized in the river, and Maggie and Tom drown in each other's arms.

Eliot's real characters were representation of human beings facing real problems. Most of her female figures are faced with the same social restrictions and the same responsibilities as the women had in Victorian era. Eliot as one of the leading novelists being familiar with women's limitations draws them perfectly in a way that arouses its reader's sympathy. During this era women faced many restrictions such as they did not have suffrage rights, the right to sue, or the right to own property. Mary Anne Evans who wrote under the pseudonym of George Eliot was familiar with these problems and felt them by her whole entity.

The idea of male superiority and female inferiority in physical, intellectual aspects leads women to cry for their natural rights they have deprived of. So the patriarchal society sees women as the Angel in the House and destructive sensual temptresses, Therefore, the female figure had no choice except being a slave, doing house choirs, bearing children, and serving husbands. Liberation has been a controversial subject during the history. All women are not strong enough to stand against the clichés and shout freedom so they accept the normality. On the other side, there are women who severely challenge this idea, try to change the beliefs and show their capabilities. They rebel against the limitations and ask for Women's Liberation that has its roots in the ideas taken from the Black Liberation movements in America (Curthoys, 1997, p.14).

Here, the researcher tries to discuss women's liberation and the oppression as represented by Maggie Tulliver, the protagonist of The Mill on the Floss, an impetuous girl who has suppressed by her beloved brother, family and society, and to show how she is oppressed, and how she protests the oppressions to gain freedom. This nonel is one of the most psychologically acute literary portrayals of girlhood in English literature. Maggie's "acute sense of her own female "slavery" reflects some of the early frustration that resulted in...depressions"(Gilbert \& Gubar 800). Even the cultural "norms" of her community deny her intellectual and spiritual growth. According to these norms, "she is an inferior, dependent creature who will never go far in anything, and which consequently are a denial of her full humanity" (Ermarth, 1974, p.587).

Maggie finds herself caught in a web of conflict with her family and community. She struggles between impulse and duty to define herself as an individual sometimes involved in self-denial and sometimes in ignorance. Here, Eliot uses the relationships of the protagonist as a medium to convey various aspects of human social associations. Her inner self is in conflict with society she lives in; she does not fit into the value system of her time and society where women were treated as the second sex, remaining at home, and raising children without education and social activity. Jean Giraudoux in Tigers at the Gates Duel of Angels (1963) states: "I have been a woman for fifty years, and I've never been able to discover precisely what it is I am" (www.bra...) "We want freedom and culture for woman because subjection and ignorance have debased her" (Eliot \& Ashton, 2009, p.186). Eliot shows the dilemma she, as a female writer, has faced while writing fictional manuscript. She cannot define "female" although she is a woman, she says: woman's hopes are woven of sunbeams; a shadow annihilates them (Miner, 2005, p.473).

The Mill on the Floss emphasizes on injustice imposed on women. Maggie, belonging to minority, rebels against injustice and escapes from social forces. She wants to be accepted for who and what she is, not pushed to be something she is not, so her weird actions, like her haircut, are considered as a kind of breakaway, a shame. As said aunt Glegg in her loudest severest tone of reproof "Fie, for shame! Little gells as cut their own hair should be whipped an fed on bread and water" (Eliot, 1994, p.76). She is repeatedly scolded by her family, relatives and even her beloved brother, who say "I wish Lucy was my sister" (p.96), because of not obeying the typical life styles and being just herself not a puppet 
performing the dominant rules. All the pressures cause her escape to gypsies whom she thinks are better than her own family.

By the rise of the 19th century, women started to change, they became more educated, bearing fewer children, and started social activities. Adapting with new reforms was so difficult not also with men but also for women who were used to the old pattern. The Mill on the Floss is written in such a social condition and Maggie is its offspring, an independent individual who uses her intellectual and tries to throw away the old patterns of masculine and feminine. Women had no independent means of subsistence so they had to obey men who held all the resources. "Girls received less education than boys, were barred from universities, and could obtain only low-paid jobs" (Wojtczak, 2011, p.1). The Mill on the Floss artistically depicts the condition of the time and suffocating rules for women who were busy by the trifles.

Although Tom is less intelligent than Maggie, he receives higher education. Maggie's intelligence is disregarded and she was banned even from reading such books as "The 'History of the Devil', by Daniel Defoe, -not quite the right book for a little girl," said Mr.Riley. "How came it among your books, Mr. Tulliver?" (Eliot, 1994, p.14). He offered Maggie to read "Aesop's Fables" and a book about kangaroos and things, and the "Pilgrim's Progress" (p.15). Mr. Tulliver knows that Maggie is brighter than her brother but he is under the influence of social constructs that hinders him from paying attention to Maggie's education. Said Mr. Tulliver, 'she's twice as 'cute as Tom. Too 'cute for a woman, I'm afraid,' ... 'It's no mischief much while she's a little un, but an over 'cute woman's no better nor a long-tailed sheep she'll fetch none the bigger price for that.' (p.8)

Eliot uses this novel as an instrument to indicate the change of women's social position and to depict the woman as a human being with all human's rights not a subject which can be played with. Obviously, all these oppressions start from the nuclear family where Greer believes that is the bad environment for raising children and women and represses women sexually, "devitalizes them, rendering them Eunuchs." We see here that Maggie's mother, her brother, and even her relatives are her main obstacles and suppressors who do not let her flourish and prevent her using her intelligence (Greer, 2006, p.256).

After the American Revolution everyone believed that freedom was given to all but it was nothing more than contradictory statements, an illusion for women's rights and equality. It helped women to improve their social position but the changes of that time were not enough for them, it just gave a new light to the women who had been looked down on. Although Maggie is born in a high-class family with a good financial and social background, she is still suffering of gender difference and abdicating from education. Mr. Tulliver, as an aware father is tender toward Tom's education but he does not care about education of intelligent Maggie "What I want, you know," said Mr. Tulliver,--"what I want is to give Tom a good eddication" (Eliot, 1994, p.5). He is not a careless father but society creates such a view about women. It led Maggie to revolute against the social constraints one of which was the typical appearance of the girls in Victorian period she lacks, as her mother scorns her for, for example, not having her hair brushed: 'Maggie,' said Mrs. Tulliver, beckoning Maggie to her and whispering in her ear as soon as this point of Lucy's staying was settled, 'go and get your hair brushed - do, for shame. I told you not to come in without going to Martha first, you know I did.' (p.60). Maggie's hair is not her main problem, this is just a way for showing her complaints and rebelling against the stereotypes. She decides to cut her hair and to get rid of them. "Her cheeks were quite flushed;" in Tom's view, "Maggie would look so queer," (p.16). By this action she does not achieve her goal but at least she expresses her irritation and shows that she cannot keep quite.

Maggie's revolutions are drastic: her escape to gypsies, her secret friendship with Philip Wakem, and her relationship with Stephen Guest, Lucy's fiancée, just like Eliot's personal life living with the married George Henry Lewes. Greer argues that change comes about by Revolution not Evolution as Maggie rebels against the social conventions and approves that she is mind not just the female appearance and hair. She revolts against the norms and escapes with the one whom she loves, and her bravery is admirable.

\section{ELIOT'S MIDDLEMARCH IN THE LIGHT OF GERMAINE GREER'S IDEAS}

Middlemarch is centered on the lives of the residents of Middlemarch, a fictitious Midlands town. Parentless after twelve years old, Dorothea and her younger sister Celia are brought up in Switzerland. When Dorothea comes to the age of twenty they return to England to live with their uncle (Chou, 2000, 3) Mr. Brooke. Dorothea accepts Mr. Casaubon's offer of marriage. Mr. Casaubon is a scholar much older than her. On their honeymoon, they experience the first tensions. Dorothea finds that her husband has no interest in involving her with his intellectual pursuits, which was her chief reason for marrying him. She meets Will Ladislaw, Casaubon's younger cousin (www.en.w...), and the two become friend. Following these differences and no mutual understanding, soon her marriage and her hopes encounter collapse. Suffering a heart attack and poor health, Casaubon asks her to promise to "do what I should desire." He dies before she can reply. Later, she learns of a provision in his will that, if she marries Ladislaw, she will lose her inheritance. Ladislaw is secretly in love with Dorothea but keeps this to himself, having no desire to involve her in scandal or to cause her disinheritance. Ladislaw decides to leave the town and visits Dorothea to say his farewell. But Dorothea has also fallen in love (R.K.Narayan, 1960, 5) (www.kcz...), and renounces Casaubon's fortune. She shocks her family by announcing that she marries Will Ladislaw. By reaching to the end of novel, the ambitious intelligent protagonist finds out that the social obstacles force her give up. 
Middlemarch was written between 1869 and 1872, shortly after the passage of Britain's reform bill (1867). This coincidence was intentional. Eliot wants to show this evolution; she "tacitly teaches that effective public reform depends first and last on personal reform" rather than politics (Kass, 2010) (www.hud...). Middlemarch is "one of the few English novels written for grown-up people" (Sokhanvar, 2003, p.884). Dorothea, the female protagonist, scorns the social constraints on women. She is an exceptional woman, intelligent, beautiful, and strong-willed from a wealthy family yet she prefers to dress plainly. The heroines of Eliot's novels share "the ex-officio disability of being a woman." For Dorothea as for others, this disability is associated with ignorance, the absence of a vocation, and the desire for knowledge" such as great men know. Despite the tendency toward women's suppression, there is a sense of gratitude to women like Dorothea who has got all the makings of a Victorian heroine: beauty, intelligence, desire for knowledge and excellence (Gilbert \& Gubar,1996, p.802). She is obsessed with grand social reform, improving the quality of poor people's lives although her social reality and idealism do not coincide. She yearns to do something lofty, to live a "life beyond self' but the social conventions and restrictions make these dreams inaccessible. This leads her to marry an old scholar whom she hopes to live out her dreams through.

Her firm decision for marriage is formed by the learning motivation she feels that she will be able to learn from Mr. Casaubon. "Everything I see in him corresponds to his pamphlet on Biblical Cosmology" (p.42). She thinks that her husband will help her to enter the world of knowledge which is unreachable for her; she marries him because she thinks he has got "a great soul" despite misgivings of Celia calling him "ugly." To Dorothea, "It is so painful ... [to] look at human beings as if they were merely animals with a toilette, and never see the great soul in a man's face" (Eliot,1965, p.42). She is so enthusiastic to prepare herself for her duties as Mrs. Casaubon. She asks, "Could I not be preparing myself now to be more useful... could I not learn to read Latin and Greek aloud to you?" and Mr. Casaubon answers, "I fear that would be wearisome to you" (p.87).

Although it is unfeminine, she starts learning Greek or Latin to help her husband with his project but in fact for her own sake, justified by notions of wifely duties. The social constraints placed on women force her to take a circuitous route to wisdom. She tries to be wise herself rather to have a wise man, and the only reason of her marriage was to be taught by him. Likewise, Casaubon hopes for someone to comfort and serve him and wishes Dorothea to be a "housemaid" while she is in search of knowledge, improvement, and excellence. At first, she thinks this marriage will provide them happiness. Gradually, realizing the differences and no mutual understanding, she abandons the idea of equality and confesses to her fault and soon their marriage encounters collapse. She distances herself from her expected roles, moving beyond her first failed marriage to wiser, and more reasonable second marriage. She is in the reaction of a rebellious anger stronger than any she had felt since her marriage. So, instead of tears there came words: "What have I done-what am I-that he should treat me so? He never knows what is in my mind - he never cares. What is the use of anything I do" (p.265)?

Having lost her way, she sits and sees as in one glance all the paths of her young hope she would never find again. She sees her own and her husband's solitude in the miserable light. There is not any trace of "Great Soul" any more yet Dorothea is now able to see the dark side of his soul. The young girl who is obsessed with lofty social reform and has a passionate and ideal nature, now changes to a girl who is frustrated with family and social conventions and so compromises and accepts the present condition. Now she is thinking, "Is he worth living for?" Now she said bitterly, "It is his fault, not mine" (265). Was it her fault that she had believed in him and his worthiness? Is her reward for being courageous to shut her best soul in prison? In the jar of her whole being, Pity was overthrown. All these feelings brought her up to take revenge, to do something. She had never deliberately allowed her resentment to govern her in this way before, but she must tell him the truth about her feelings. It is good that he should wonder and be hurt.

As a girl of "open and ardent" (Eliot, 1965, p.9) energy, Dorothea is unsatisfied with the strict sexual role the Middlemarch society designates to women. For example, when she offers to help his uncle with his work, he declines it, saying "young ladies are too flighty" (Eliot, 1965, p.18). She often wants to join man's talks but she is annoyed at "being twitted with her ignorance of political economy, that never-explained science which was thrust as an extinguisher over all her lights" (p.17). Yet to men, this girlish ignorance is natural for a woman. As her uncle explicitly expresses, "I don't pretend to argue with a lady on politics...Your sex are not thinkers" (p.49). In fact, a female in this society does not need to know anything about politics because the social custom evaluates a marriageable girl by "good looks, vanity, and merely canine affection" (p.8). So, Dorothea's eagerness to develop people's life is considered eccentric for a young lady. What a woman should do is to be able to "sit down and play" or sing "a good old English tune" (p.58).

She enjoys the features valuable for women of the time, her uncle gives her some freedom of act, like freedom for marriage, many women lacked. However, she is suppressed in some others aspects by her uncle: "Young ladies don't understand political economy" (p.39). In contrary, Rosamond Vincy, the beautiful daughter of the mayor, looks at things from the proper feminine angle. She belongs to the majority of women who accepts the current situations and follows them with no complaint. She competes with Dorothea who is beautiful, too but her beauty is of a different type. Dorothea is womanly and maternal, frequently compared to a saint. Rosamond is described as "infantine." The contrast between them is even played out in their names, Dorothea means "gift of the gods," Rosamond means "rose of the world," thoroughly human (Vincey, p.1) (www.shm...). 
She represents one stereotypical view of women and has been trained to be a wife by her defined responsibilities. In spite of going to an expensive school in which being a woman is taught she scorns the social constraints on women and she does not limit herself to the proper education for women. Dorothea and Rosamond's images are depicted "Within particular web" of Middlemarch, respectively as the "dark heroine" who shuns the male gaze when not oblivious to it and the "fair femme fatale" who revels in it" (Eliot, 1965, p.170).

It seems that the events in Middlemarch take place between 1829- 1832 so "most of the historical references in the novel concern events and personalities involved in the struggle for political reform" (Beaty, 1957, p.1). During this time, the atmosphere of England was suffocating for women to aspire, they had a few limited tasks to do with no room of their own. Most of them got used to the stereotypes yet there were some exceptions being fed up with this condition and began to rebel for some changes. In such a society, Dorothea is born and grew up with different points of view toward world, longing for doing noble projects and deeds. Like most of women in Victorian period, her responsibilities were restricted to the domestic sphere. She seeks for reformation, and thinks that marriage to a scholar like Mr. Casaubon satisfies her inexpressible longings, unfortunately in a very short time she finds out her husband is too tied up in his own little world to mark her and her ambitions, so she is left desperate by her wrong marriage.

As mentioned before, Greer believes that change is brought up by Revolution not Evolution. She rejects reformation. On Contrary to Greer's revolutionary idea, Dorothea does not go for revolution, she is just seeking for reformation, and so achieves nothing but despair. Dorothea and Will's marriage sheds light also on Eliot's teaching regarding political reform: effective political reform begins with personal moral reform. In marrying Dorothea to Will, the man devoted to political reform, "Eliot literally embodies reform's abiding need for sympathetic understanding, for learning to see the world through the eyes of another. What better way to demonstrate the importance of private and spiritual means for the pursuit of salutary political ends?" "(Kass, 2010, 3-5).

Celia calls her sister "dodo," an extinct flightless bird; the parallels between the lives of the dodo birds and Dorothea's reveal how life for Victorian women happens in a series of aviaries built by a male-chauvinistic society, keeping them flightless and oppressed. Representing Dorothea's various cages, which take the form of the frustratingly confining world of her girlhood and the suffocating "virtual tomb" (Middlemarch 295) of her marriage, Eliot tries to save women's souls, passions, and talents from extinction (Jones, 2012, p.1). The idea of Dorothea's various cages is a pure truth, but her the main cage is her male-centered society of which there is no escape. Moreover, some other cages are her uncle's house, the cage of Mr. Casaubon, and the last cage in which she is voluntarily poisoned is Will Lydgate's political ambitions. It might not be a wrong claim if we consider female figure as a sacrifice figure.

Dorothea is the victim of her society and social norms which do not accept her as a human with natural desires but as a slave who should forget her ambitions because reforms do not occur. This idealistic heroine has her ambitions and ideals crushed and perverted by the suffocating atmosphere in the androcentric society where girls and women are totally ignored while great deals of values are given to the male, and the only solution for getting out of this situation is the Revolution as Greer over and over repeated it in a loud voice.

\section{CONCLUSION}

Greer introduces some novel ideas in the realms of women's liberation, nuclear family, and revolution. She rebels against women's suppression in modern society and tries to get rid of the old clichés rooted in family as the first enemy for women, feminized with the sense of inferiority. In her opinion women's liberation as to be distinct from equality with men and how to gain freedom in order to dominate their own fates and stand upon female castration which starts from the smallest unit of society and later ends in all types of communities. Women's liberation does not mean equality with men but liberation over our fate. She refers to nuclear family as a bad environment for women because of suppressing and making them selfless; and women's true position is not obtained in masculine, dogmatic society except by revolution. Greer tries to keep women closer to their liberation. Her theories are applied in Eliot's Mill on the Floss and Middlemarch. Although these novels are written almost in the same decade, their protagonists are not typical girls, and act differently.

Maggie is a real example of a suppressed girl in search of self-acceptance never received. She is always in conflict with her desires and the outward forces, she is not allowed to grow up and even is blamed for what she reads. Her life is restricted by dogmatic rules of her family and society. In spite of these limitations she is successful to achieve her educational goals. For Eliot Maggie is a rebellious figure who tries to fight against oppressive society and her weapon is her bravery and courage. Regardless to the outcomes, she follows her ambitions, and acts bravely, doing perky actions like her escape to gypsies, cutting her hair, her friendship with Philip, and her relationship with Stephen, but sometimes she compromises because the social conventions are deeply rooted and cannot be easily overcame. Maggie needs freedom to be herself not a copy of stereotypes, she hates blindly imitation, she wants freedom of action, not to do what the society expects her to do, or to be inhibited from achieving her goals. By acting abnormally in a traditional society, Maggie proves that she is able to make grand changes and achieves liberty.

Dorothea, on the other side, is a girl with a respectable character who even before marriage has her own social activities and receives a sense of gratitude. She is in search of freedom of thought, she longs for excellence and knowledge while the common women are busy with their house choirs. Nevertheless, she is not courage enough to firmly rise against the conditions and restrictions of the time, she surrenders to marry an old scholar, wishing it will 
allow her to become educated but soon she finds out that her dominant wish is doomed to failure and she cannot extinguish her thirst for education. Thus, she compromises to the suppressing society, surrenders to her fate and gets along with what fate offers her. She not only fails to gain liberty and to do grand jobs but also she acts too weakly to make change in her community to achieve her goals. And as a total loser, she makes serious mistakes that cause her great unhappiness. After Mr. Casaubon's death, she marries again perhaps seeking her goals in the other marriage by sacrificing her wishes for her husband who tries to achieve his political targets. It did not help her to materialize her ideals but causes her to put all of them away.

Considering Maggie and Dorothea's condition, we find Maggie's life more successful than her counterpart's because Maggie knows her goals and fights for it voluntarily. She aims to reach freedom of thought and act, and embraces its outcomes. In doing so she separates from her family and she sacrifices all their supports to gain freedom. Rigid Dorothea lacks Maggie's bravery and so she is not able to create a revolution in her situation. And finally, she succumbs to current conditions. Both of them are stubborn figures belonging to minority with big ambitions which are different from the majority of women of the time. They know what they want and are ready to fight for it. Maggie's self-study and Dorothea's effort for learning Greek and Latin are admirable.

\section{REFERENCES}

[1] Abrams, M. H (1999). A Glossary of Literary Terms. Seventh edition. Massachusetts: Earl McPeek.

[2] Beaty, Jerome. (1957). Victorian Studies: History by Indirection: The Era of Reform in Middlemarch. Vol. 1. Indiana University Press. Pdf.

[3] Bressler, Charles E. (1994). Literary Criticism. New Jersey: Englewood Cliffs.

[4] Clegg, Stewart, James R. Bailey. (2008). International Encyclopedia of Organization Studies, Volume 1.

[5] Cuddon, J.A. (1984). A Dictionary of Literary Terms. Rev. ed. Middlesex: Penguin Books.

[6] Darwin, Charles. (1986). The Descent of Man and Selection in Relation to Sex. New York: D. Appleton and Company.

[7] Eliot, George. (1965). Middlemarch. Ed. W. J. Harvey. Baltimore: Penguin Books.

[8] Eliot, George. (1994). The Mill on the Floss. Baltimore: Penguin Books.

[9] Gilbert, Sandra M and Susan Gubar, eds. (1996). The Norton Anthology of Literature by Women, 2nd ed. New York: Norto.

[10] Grabes, Herbert et al. The Yearbook of research in English and American literature, Fludernik, Monika

[11] "Subversive Irony, Reflectorization, Trustworthy, Narration and Dead-Pan Narrative in The Mill on the Floss." Vol 8. (1989) New York: Aufnahme.

[12] Green, Laura Morgan. (2001). Educating Women: Cultural Conflict and Victorian Literature. Athens: Ohio University Press.

[13] Greer, Germaine. (2006). The Female Eunuch. London: HarperCollins.

[14] Greer, Germaine. (1999). The Whole Woman. London: Doubleday.

[15] Greer, Germaine. (2011). Untamed Shrew by Christine Wallace, Pan MacMillan, review by Ann Skea.

[16] Lidström Broc, Malin. (2016). The Biographical Battles over Betty Friedan, Germaine Greer, Gloria Steinem, and Simone de Beauvoir

[17] Montessori, Maria. (2004). The Montessori Method, The Origins of an Educational Innovation: Including an abridged and annotated Edition of Maria Montessori's The Montessori Method, published in the United States of America by Roman \& Littlefield publishers.

[18] Nicholson, Joyce. (1980). What Society Does to Girls, Virago Book; 2nd Edition.

[19] Parlett, Mathilde. "The influence of contemporary criticism on George Eliot". Southeastern United States.

[20] Wojtcza, Helena. (2014). Women's Status in Mid 19th-Century England a Brief Overview.

[21] https://www.brainyquote.com/quotes/jean_giraudoux_387066.

[22] http://www.eclectica.org/v2n3/skea_greer_untamed_shrew.html >.

[23] https://www.hudson.org/.../researchattachments/attachment/.../sympaty_love_and_mar.

[24] University of North Carolina Press, (2007) 7. Feb.2011.

[25] <http://www.jstor.org/pss/4172196>girls.

[26] http://kczx.hnu.cn/G2S/Template/View.aspx?courseId=824\&topMenuId=192762\&action=view\&type=1\&name=\&menuType= $1 \&$ curfolid=245749.

[27] https://kimberlytruesdale.wordpress.com/.../small-things-if-freedom-is-an-out-of-body.

[28] https://newleftreview.org/I/66/branka-magas-sex-politics-class-politics.

[29] https://plato.stanford.edu/entries/feminism-family.

[30] https://twitter.com/DrHannahDawson/status/94467310967159603.

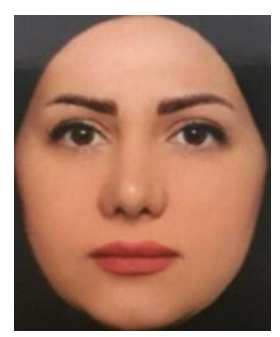

Hasti Solitani was born in 1985 in Tehran. She earned her Master's degree in English Literature in 2012 and received her bachelor's degree in the same field in 2007.

She is currently teaching at Ershad University in Tehran. She has taught English courses at Ershad University in Tehran and Damavand since 2013 and also has taught English in different schools and institutes since 2004. Her main research interest is in literature with a focus on gender, and educationally related issues 